\title{
Review Article \\ Hypoxic Culture Conditions as a Solution for Mesenchymal Stem Cell Based Regenerative Therapy
}

\author{
Nazmul Haque, ${ }^{1,2}$ Mohammad Tariqur Rahman, ${ }^{3}$ \\ Noor Hayaty Abu Kasim, ${ }^{1,2}$ and Aied Mohammed Alabsi ${ }^{4,5}$ \\ ${ }^{1}$ Regenerative Dentistry Research Group, Faculty of Dentistry, University of Malaya, 50603 Kuala Lumpur, Malaysia \\ ${ }^{2}$ Department of Conservative Dentistry, Faculty of Dentistry, University of Malaya, 50603 Kuala Lumpur, Malaysia \\ ${ }^{3}$ Department of Biotechnology, Faculty of Science, International Islamic University Malaysia, 25200 Kuantan, Malaysia \\ ${ }^{4}$ Dental Research and Training Unit, Faculty of Dentistry, University of Malaya, 50603 Kuala Lumpur, Malaysia \\ ${ }^{5}$ Oral Cancer Research \& Coordinating Centre, Faculty of Dentistry, University of Malaya, 50603 Kuala Lumpur, Malaysia
}

Correspondence should be addressed to Noor Hayaty Abu Kasim; nhayaty@um.edu.my

Received 3 July 2013; Accepted 26 July 2013

Academic Editors: H. Acker and M. Nikinmaa

Copyright (C) 2013 Nazmul Haque et al. This is an open access article distributed under the Creative Commons Attribution License, which permits unrestricted use, distribution, and reproduction in any medium, provided the original work is properly cited.

\begin{abstract}
Cell-based regenerative therapies, based on in vitro propagation of stem cells, offer tremendous hope to many individuals suffering from degenerative diseases that were previously deemed untreatable. Due to the self-renewal capacity, multilineage potential, and immunosuppressive property, mesenchymal stem cells (MSCs) are considered as an attractive source of stem cells for regenerative therapies. However, poor growth kinetics, early senescence, and genetic instability during in vitro expansion and poor engraftment after transplantation are considered to be among the major disadvantages of MSC-based regenerative therapies. A number of complex inter- and intracellular interactive signaling systems control growth, multiplication, and differentiation of MSCs in their niche. Common laboratory conditions for stem cell culture involve ambient $\mathrm{O}_{2}$ concentration (20\%) in contrast to their niche where they usually reside in 2-9\% $\mathrm{O}_{2}$. Notably, $\mathrm{O}_{2}$ plays an important role in maintaining stem cell fate in terms of proliferation and differentiation, by regulating hypoxia-inducible factor-1 (HIF-1) mediated expression of different genes. This paper aims to describe and compare the role of normoxia $\left(20 \% \mathrm{O}_{2}\right)$ and hypoxia $\left(2-9 \% \mathrm{O}_{2}\right)$ on the biology of MSCs. Finally it is concluded that a hypoxic environment can greatly improve growth kinetics, genetic stability, and expression of chemokine receptors during in vitro expansion and eventually can increase efficiency of MSC-based regenerative therapies.
\end{abstract}

\section{Introduction}

The promising role of stem cell therapy is becoming more conceivable in addressing the unmet needs of treating degenerative diseases through conventional medicine. Diseases such as diabetes, myocardial infarction, spinal cord injury, stroke, and Parkinson's and Alzheimer's diseases have become more prevalent with increasing life expectancy. It has been estimated that in the United States alone, approximately 128 million individuals would benefit from regenerative stem cell therapy during their lifetime [1].

Self-renewal and multipotency are the key hallmarks of stem cells, permitting them to act as the fundamental units maintaining growth, homeostasis and repair of many tissues. These two key features establish stem cells as the most promising tool for regenerative medicine $[2,3]$. Among the different types of stem cells, mesenchymal stem cells (MSCs) or multipotent mesenchymal stromal cells [4] are considered as a potential tool to treat degenerative diseases. This is due to their multipotent differentiative capacity [5-7] with trophic activity $[8,9]$, potent immunosuppressive effects [10-12], and ability to induce vascularisation [13]. Moreover, MSCs can be efficiently isolated from tissues such as bone marrow, adipose tissue, umbilical cord, and dental pulp [14-17]. These properties have fascinated and encouraged researchers to push the frontiers of regenerative medicine, utilizing MSCs 


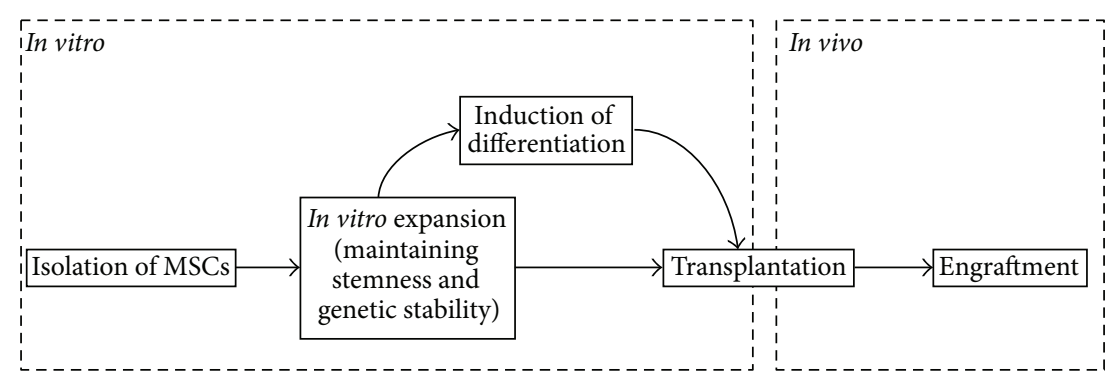

FIgURE 1: Steps involved in MSCs-based therapy.

to treat a large variety of pathologies, including traumatic lesions, stroke, autoimmune diseases, musculoskeletal and cardiac disorders [18-21].

Despite the various sources, concentration of MSCs within tissues is very low $[22,23]$, and it is not possible to isolate 50-200 million MSCs (typically used in clinical trials) from a donor for each therapy [24-29]. Thus, in vitro expansion of MSCs has become an inevitable option [23]. In several clinical trials, MSCs expanded in vitro are being transplanted to find out their efficacy in treating degenerative diseases, reducing acute rejection of transplanted organs, and in preventing and treating graft-versus-host disease $[25,29-$ 32]. Sometimes the expanded cells are induced to differentiate into a particular cell type and then the predifferentiated cells are transplanted for the regeneration of particular tissues or organs [33]. After transplantation, tissue-specific migration and engraftment ensure the success of cell-based regenerative therapy.

From isolation to engraftment, the MSCs usually pass through two different environmental conditions. One is the in vitro culture condition (from isolation to transplantation) and the other is the in vivo or physiological condition (before isolation and after transplantation) (Figure 1). At present, most of the expansion procedures of MSCs are performed under ambient $\mathrm{O}_{2}$ concentration, where cells are exposed to $20 \% \mathrm{O}_{2}$, which is approximately 4-10 times more than the concentration of $\mathrm{O}_{2}$ in their natural niches $[35,36]$. The higher $\mathrm{O}_{2}$ concentration might cause environmental stress to the in vitro cultured MSCs. Moreover, in recent years, several studies have presented clear evidence regarding the negative influence of ambient $\mathrm{O}_{2}$ concentration on MSCs, including early senescence, longer population doubling time, DNA damage [37, 38], and poor engraftment following transplantation $[33,39]$. All these have shown the influential effect of $\mathrm{O}_{2}$ concentration on MSCs biology and raised serious concern over its therapeutic efficiency and biosafety.

Numerous in vitro studies have been conducted in the last two decades to analyze the complex processes involved in stem cell maintenance. However, the role of physiologically normoxic (hypoxic) conditions (usually $2-9 \% \mathrm{O}_{2}$ concentration) on stem cell biology received very little attention [40]. Thus, this paper discusses the differences between in vitro MSC culture in ambient and hypoxic conditions. Finally this paper also highlights how MSCs cultured in vitro in hypoxic conditions can offer a solution for MSCs-based therapy.

\section{Stem Cell Niche}

In both in vitro and in vivo conditions, the fate and function of stem cells depend upon their intrinsic genetic program and the local microenvironment, often referred to as the "stem cell niche" [41]. The stem cell niche concept was proposed by Schofield in 1978 [42], and several researchers have tried to elucidate the confusion and controversy over it [43-45]. "Stem cell niche" can be defined as the anatomical compartment composed of cellular and acellular components that orchestrate both systemic and local signals to control the rate of stem cell proliferation, to determine the fate of stem cell daughters, and to protect stem cells from exhaustion or death [46-48]. The cellular and acellular components of the stem cell niche can be divided into four main groups of key factors, namely, the regulatory molecules $\left(\mathrm{O}_{2}\right.$, nutrients, and cytokines), other cells (3D context, cell-cell contacts, autocrine, and paracrine signals), extracellular matrix (immobilized and released factors, structure, topology, and stiffness), and physical factors (flow shear, compression, stretch, and electrical signals) [41].

2.1. The Hypoxic Embryonic Stem Cell Niche. In mammals, from fertilization to parturition, cells within the embryo face continuously change in $\mathrm{O}_{2}$ concentration [49]. During the time of blastocyst implantation, $\mathrm{O}_{2}$ levels within the lumen of the uterus remain as low as $1-2 \%$ [50]. In human tissues, $\mathrm{O}_{2}$ has a diffusion distance of approximately $150 \mu \mathrm{m}$ $[51,52]$, which regulates the $\mathrm{O}_{2}$ supply during development and implantation of the blastocyst [53]. However, after development of the circulatory system until 8-10 weeks of gestation, the placental $\mathrm{O}_{2}$ levels remain lower (approximately $2-3 \%$ ) than those in the surrounding endometrium and reach physiological $\mathrm{O}_{2}$ concentration at the 12-13th week of gestation $[54,55]$. Therefore, embryos go through hypoxic $\mathrm{O}_{2}$ concentrations while passing through different developmental periods. Among all the embryonic stages, blastocyst which resides in a hypoxic environment has been recognized as the main source of pluripotent embryonic stem cells (ESCs).

Recently, a new type of pluripotent stem cell has been generated by reprogramming human adult somatic cells. Pluripotency of this cell type is comparable to human ESCs and commonly referred as "induced pluripotent stem cells" 
TABLE 1: Oxygen concentration in different organs and tissues.

\begin{tabular}{lcc}
\hline Name of the tissue or organ & Oxygen concentration & References \\
\hline Lung parenchyma & $4 \%$ to $14 \%$ & {$[64,65]$} \\
Circulation & $4 \%$ to $14 \%$ & {$[63,66]$} \\
Liver & $4 \%$ to $14 \%$ & {$[64,67]$} \\
Kidneys & $4 \%$ to $14 \%$ & {$[64,68]$} \\
Heart & $4 \%$ to $14 \%$ & {$[69,70]$} \\
Brain & $0.5 \%$ to $8 \%$ & {$[71-73]$} \\
Eye (retina, corpus vitreous) & $1 \%$ to $5 \%$ & {$[74,75]$} \\
Bone marrow & $1 \%$ to $6 \%$ & {$[35,36,76]$} \\
Adipose tissue & $2 \%$ to $8 \%$ & {$[62]$} \\
\hline
\end{tabular}

(iPSCs) [56]. Hypoxic culture environments have shown to enhance the generation of these iPSCs too $[57,58]$.

\subsection{The Hypoxic Environment of the Mesenchymal Stem Cell} Niche. Like ESCs, MSCs also reside in low $\mathrm{O}_{2}$ concentrations. In mammals including humans, MSCs are located in perivascular niches close to the vascular structure in almost all tissues [17, 59, 60]. Despite residing near the blood vessels, in different tissues where they are found, the $\mathrm{O}_{2}$ concentrations are low $[61,62]$. In adult human tissues, $\mathrm{O}_{2}$ concentration varies widely (Table 1 ) depending on the vascularisation and the type of microenvironment within the respective organ, and they are considerably lower than the inhaled ambient $\mathrm{O}_{2}$ concentration (21\%). The partial pressure or $\mathrm{O}_{2}$ concentration of inspired air gradually decreases after it enters the lungs and then in the blood flowing from the alveolar capillaries that carry $\mathrm{O}_{2}$, towards the organs and tissues for their oxygenation. By the time $\mathrm{O}_{2}$ reaches the organs and tissues, $\mathrm{O}_{2}$ concentration drops to $2 \%-9 \%$, with a mean of $3 \%[40,63]$.

As the concentrations of $\mathrm{O}_{2}$ in blastocysts and the MSCs niches are very low $[73,76,77]$, this could be an important clue for maintaining the self-renewal property and plasticity of MSCs.

\section{Comparison between Culture in Hypoxic and Ambient Environments}

Since 1963, when the isolation and self-renewing properties of mouse bone marrow cells were first reported [78, 79], until now most of the research efforts have been focused on the identification of molecular markers [4, 80, 81]. This has allowed the isolation of different types of tissue-specific stem or progenitor cells [82-85] and has also assisted to define the differentiation of stem or progenitor cells into a particular cell type $[86,87]$. Moreover, the development of specific methods for functional stem cell isolation and identification is highly important, in order to study the molecular mechanisms behind the multipotentiality and self-renewable capacity of stem cells and also for the establishment of stem cell-based regenerative therapeutics. This trend has overshadowed the importance of $\mathrm{O}_{2}$ concentration, a key environmental factor that might play a vital role on stem cell fate and function [40]. Unfortunately till now in most laboratories, stem cells are typically cultured under the ambient $\mathrm{O}_{2}$ concentration without paying attention to the metabolic milieu of the niche in which they grow or normally reside [88]. However, in recent years, scientists have started to manipulate the $\mathrm{O}_{2}$ concentration in cell cultures by maintaining a niche-like hypoxic environment. Though the effect of hypoxic culture conditions on the proliferation and differentiation potential of MSCs has been reviewed by few researchers [77, 89], the effect of hypoxia on the genetic stability, early senescence, and site-specific migration of MSCs has not been reviewed in depth. Thus, on the basis of recent research outcomes, the effect of different $\mathrm{O}_{2}$ concentration on MSCs biology is further discussed.

3.1. Proliferation of MSCs. Capability for self-renewal is a key feature of stem cells. An increased proliferation rate is necessary for more efficient use of stem cells in regenerative therapies. Fehrer et al. (2007) demonstrated that bone marrow-derived MSCs (BM-MSCs) cultured in 3\% $\mathrm{O}_{2}$ concentration showed significantly increased in vitro proliferative lifespan, with approximately 10 additional population doublings (PDs) $\left(28.5 \pm 3.8 \mathrm{PD}\right.$ in $20 \% \mathrm{O}_{2}$ and $37.5 \pm 3.4 \mathrm{PD}$ in $3 \% \mathrm{O}_{2}$ ) before reaching senescence compared to cells cultured in the ambient $\mathrm{O}_{2}$ environment [38]. In addition, early passaged MSCs cultured in hypoxic conditions also exhibit increased proliferative lifespan along with significant difference in population doubling [37]. Furthermore, it is possible to harvest more than $1 \times 10^{9}$ MSCs from the first five passages cultured in $3 \% \mathrm{O}_{2}$, whereas in ambient condition only $2 \times 10^{7}$ cells can be obtained [37]. Higher in vitro expansion rate in hypoxic conditions has also been reported by several other researchers [90-93]. Such in vitro culture environment also allows to maintain a higher proportion of rapidly self-renewing MSCs for a longer period of time [94]. However, proliferation of MSCs was reduced significantly in $1 \%$ or less $\mathrm{O}_{2}$ concentration [95].

3.2. Plasticity of MSCs. Besides higher growth kinetics, maintaining plasticity is also an important factor for prospective use of MSCs in regenerative medicine. Trilineage (osteogenic, chondrogenic, and adipogenic) mesenchymal differentiation is a unique biological property of MSCs [4]. Several researchers reported the effect of different culture $\mathrm{O}_{2}$ concentrations on the trilineage differentiation of MSCs. In an elegantly designed experiment, Raheja et al. (2010) seeded and induced MSCs for differentiation under an atmosphere of $5 \%$ carbon dioxide $\left(\mathrm{CO}_{2}\right)$ along with 1 of $4 \mathrm{O}_{2}$ concentrations $(1 \%, 2 \%, 5 \%$, and $21 \%)$. According to their results, MSCs differentiated into osteoblast most rapidly in $21 \% \mathrm{O}_{2}$, and $\mathrm{O}_{2}$ below $5 \%$ showed reduced differentiation potential. However, no statistically significant difference in osteogenic marker was reported when $\mathrm{O}_{2}$ was between $5 \%$ and $21 \%$ [96]. In addition, Basciano et al. (2011) have reported improved osteoblastic and adipogenic differentiation potential of early passaged (P2) MSCs in 5\% $\mathrm{O}_{2}$ concentration [90]. Several other recent reports support that the multilineage differentiation potential of MSCs can be maintained under hypoxic $\left(1-5 \% \mathrm{O}_{2}\right.$ 


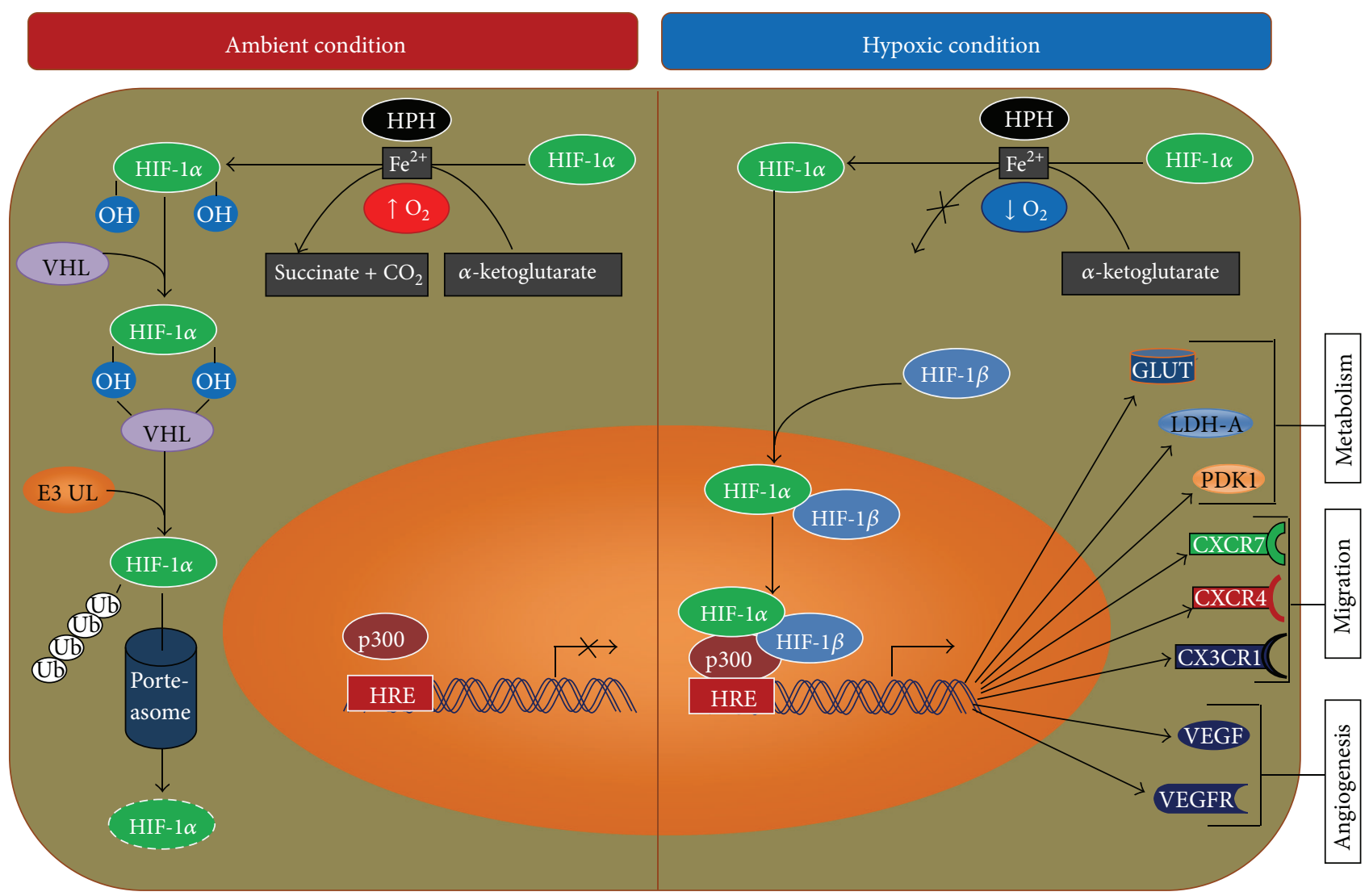

FIgURE 2: Regulation of transcription by HIF-1 during ambient and hypoxic condition. HIF: hypoxia-inducible factor; HPH: HIF-1 prolylhydroxylases; VHL: Von Hippel-Lindau; E3UL: E3 ubiquitin ligase; HRE; hypoxia-response element; GLUT; glucose transporter: LDH: lactate dehydrogenase; PDK, pyruvate dehydrogenase kinase (see text for details).

concentration) environment [91, 92, 95, 97]. Increased adipogenic and osteogenic differentiation potentials of adipose tissue-derived MSCs precultured in hypoxic environment have also been reported [98]. In contrast, few researchers showed reduction in the differentiation potential of MSCs when maintained and induced for differentiation in $1 \% \mathrm{O}_{2}$ concentration $[99,100]$.

3.3. Genetic Stability of MSCs. Genetic instability of MSCs is another major problem that is directly related to the biosafety of stem cell therapy. For instance, aneuploidy, DNA breakdown, and telomere shortening can be observed in cultured MSCs [37, 101, 102]. However, Tarte et al. (2010) reported that aneuploidy in cultured MSCs is donor dependent rather than its dependence on the culture environment [102]. In contrast, Estrada et al. (2012) have shown a negative effect of ambient $\mathrm{O}_{2}$ concentration on cultured MSCs responsible in bringing about DNA damage and aneuploidy. However, this effect was minimized by expanding MSCs in a physiological $\mathrm{O}_{2}$ concentration [37]. There is scientific evidence that aneuploidy is a major cause of tumorigenesis $[103,104]$ which raised concerns regarding the biosafety of MSCs cultured in ambient $\mathrm{O}_{2}$ condition.
3.4. Engraftment of MSCs. Engraftment is an important part of MSC therapy. Modest engraftment capacity following transplantation of MSCs cultured in ambient condition has been reported in some clinical trial reports $[33,39]$. Unpretentious therapeutic outcomes of clinical trials by using MSCs have also been reported in several review articles and metaanalysis [105-107]. Moreover, failure of in vivo engraftment of bone marrow (BM)-MSCs into nonhematopoietic tissue has been reported previously [108-110]. Various strategies can be employed to overcome this problem. For instance, in a recent publication, Jin et al. (2011) reported that the 1st passage of mouse BM-MSCs had shown better engraftment and differentiation potential to cardiomyocytes in vivo, compared to the 5th passage mouse BM-MSCs [111]. In addition, murine MSCs preconditioned in hypoxic environment showed enhanced skeletal muscle regeneration at day 7 and improved blood flow and vascular formation compared to MSCs maintained in normoxic condition [112]. Furthermore, expression of chemokine receptors CXCR4, CXCR7, and CX3CR1 was upregulated when MSCs were exposed to hypoxia or a reagent that mimics the response to hypoxia [94, 113-115]. These chemokine receptors play an important role in damaged-tissue-specific trafficking and homing of MSCs [113, 115-118]. 


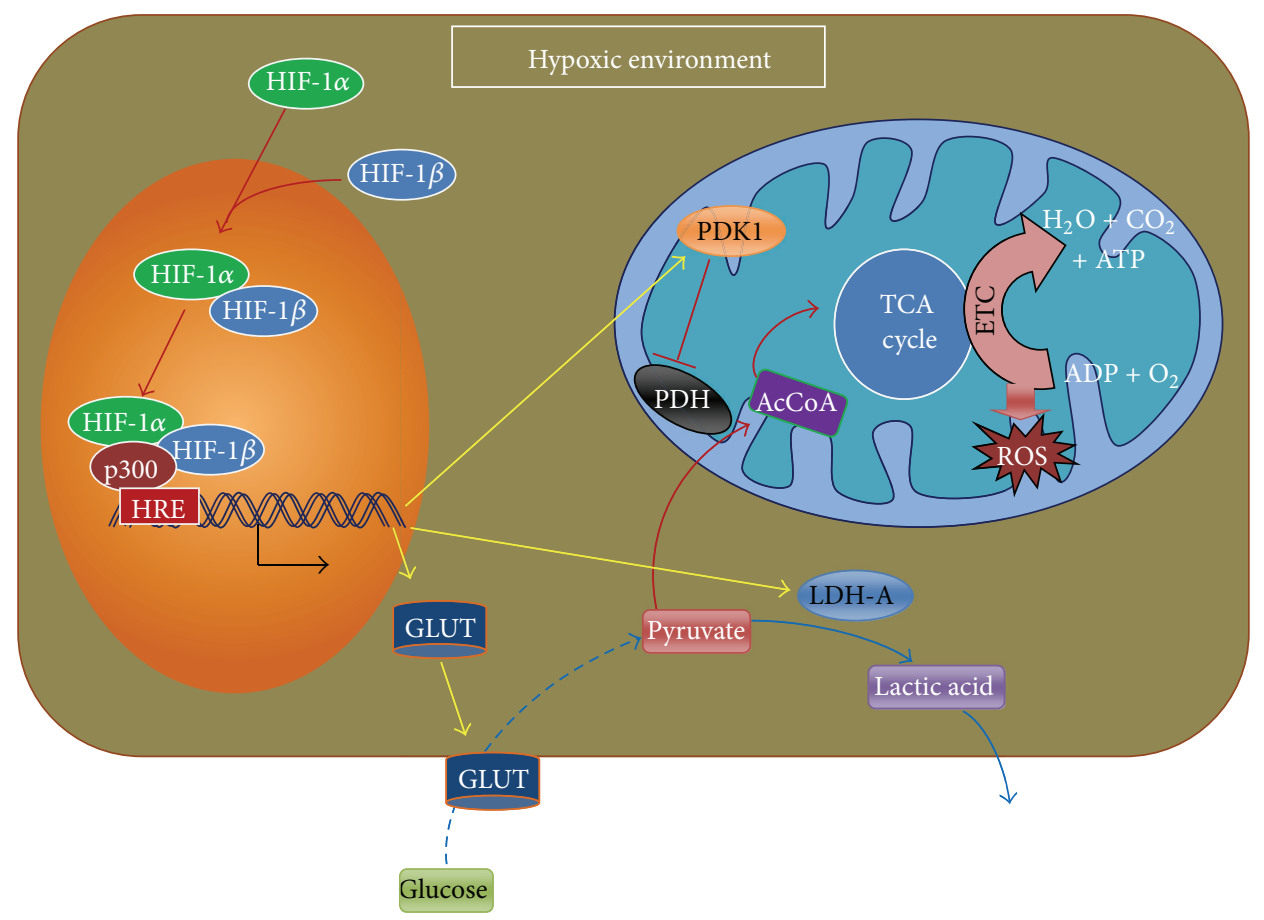

FIGURE 3: Suppression of mitochondrial respiration by HIF-1 $\alpha$ in hypoxic environment. HIF: hypoxia-inducible factor; HRE: hypoxiaresponse element: GLUT: glucose transporter; LDH: Lactate dehydrogenase; PDH: pyruvate dehydrogenase; PDK: pyruvate dehydrogenase kinase; TCA: tricarboxylic acid; ETC: electron transport chain; ROS: reactive oxygen species (see text for details).

\section{Biochemical and Molecular Changes due to Hypoxia}

$\mathrm{O}_{2}$ concentration in the stem cell niche (usually 2-9\% $\mathrm{O}_{2}$ ) is considered a driver of cell function [40]. Hypoxia plays a vital role in maintaining homeostasis within the body from the very beginning of embryonic development. It helps facilitate proper embryonic development, maintain stem cell pluripotency, induce differentiation, and regulate the signalling of multiple cascades, including angiogenesis [119]. In hypoxic conditions, usually these functions are regulated by several transcription factors such as hypoxia-inducible factors (HIFs), prolyl-hydroxylases (PHDs), factor-inhibiting HIF-1 (FIH-1), activator protein 1 (AP-1), nuclear factor (NF)$\kappa \mathrm{B}, \mathrm{p} 53$, and $\mathrm{c}-\mathrm{Myc}[120]$. Although interaction among all of the transcription factors is required for cellular response, HIFs (especially HIF-1) are the key regulators of cellular response to hypoxia [121].

4.1. Regulation of Transcription by HIF-1 during Direct Sensing of Changes in Oxygen. The HIF- $1 \beta$ subunit of a heterodimeric transcription factor HIF-1 (HIF-1 $\alpha$ and HIF-1 $\beta$ ) $[122,123]$ is nonresponsive to oxygen, whereas HIF-1 $\alpha$ is an oxygen labile protein. Therefore, under ambient condition the HIF- $1 \alpha$ subunit is usually synthesized and degraded rapidly, whereas under hypoxic conditions, its breakdown is delayed [122, 124]. Degradation of HIF-1 $\alpha$ under ambient culture condition (Figure 2) is regulated by HIF-1 prolyl-hydroxylases (HPHs) [125]. HIF-1 prolyl-hydroxylases (HPHs) in the presence of $\mathrm{O}_{2}$, iron, and $\alpha$-ketoglutarate hydroxylate the proline residues
402 and 564 of the oxygen-dependent degradation domain (ODD) of HIFl $\alpha[126,127]$, which in turn induce a conformational change of HIF $\alpha$, thus allowing Von Hippel-Lindau protein (VHL) to bind with it [62]. Consequently, VHL binds to a complex that serves as E3 ubiquitin ligase (E3UL) and ubiquitinylate HIF- $1 \alpha$ for degradation in proteasome $[63,128$, 129].

In contrast, under hypoxic conditions, the prolylhydroxylation process is suppressed due to lack of $\mathrm{O}_{2}$ that allows HIF- $1 \alpha$ accumulation and nuclear translocation to occur [124]. After nuclear translocation, it binds with HIF-1 $\beta$ to form the heterodimer. Then the HIF-1 heterodimer binds to a hypoxia-response element (HRE) in the target genes, associated with coactivators such as $\mathrm{CBP} / \mathrm{p} 300$, and regulates the transcription (Figure 2) of as many as 70 genes involved in metabolism, angiogenesis, invasion/metastasis, and cell fate [130].

4.2. Reduction of Reactive Oxygen Species by Suppressing Mitochondrial Respiration during Hypoxia. Relatively recent discoveries also support the role of HIF- $1 \alpha$ on metabolic regulation by suppressing mitochondrial respiration. In hypoxic conditions, stabilized HIF- $1 \alpha$ translocates into the nucleus and binds to HIF- $1 \beta$ to form the heterodimer, which in turn binds to the target gene-specific HREs to transcriptionally activate genes that code for glucose transporters (GLUT), glycolytic enzymes, and lactate dehydrogenase-A (LDH-A) to facilitate anaerobic respiration [130, 131]. Besides suppression of mitochondrial respiration, HIF- $1 \alpha$ promotes the expression of pyruvate dehydrogenase kinase (PDK) that prevents 


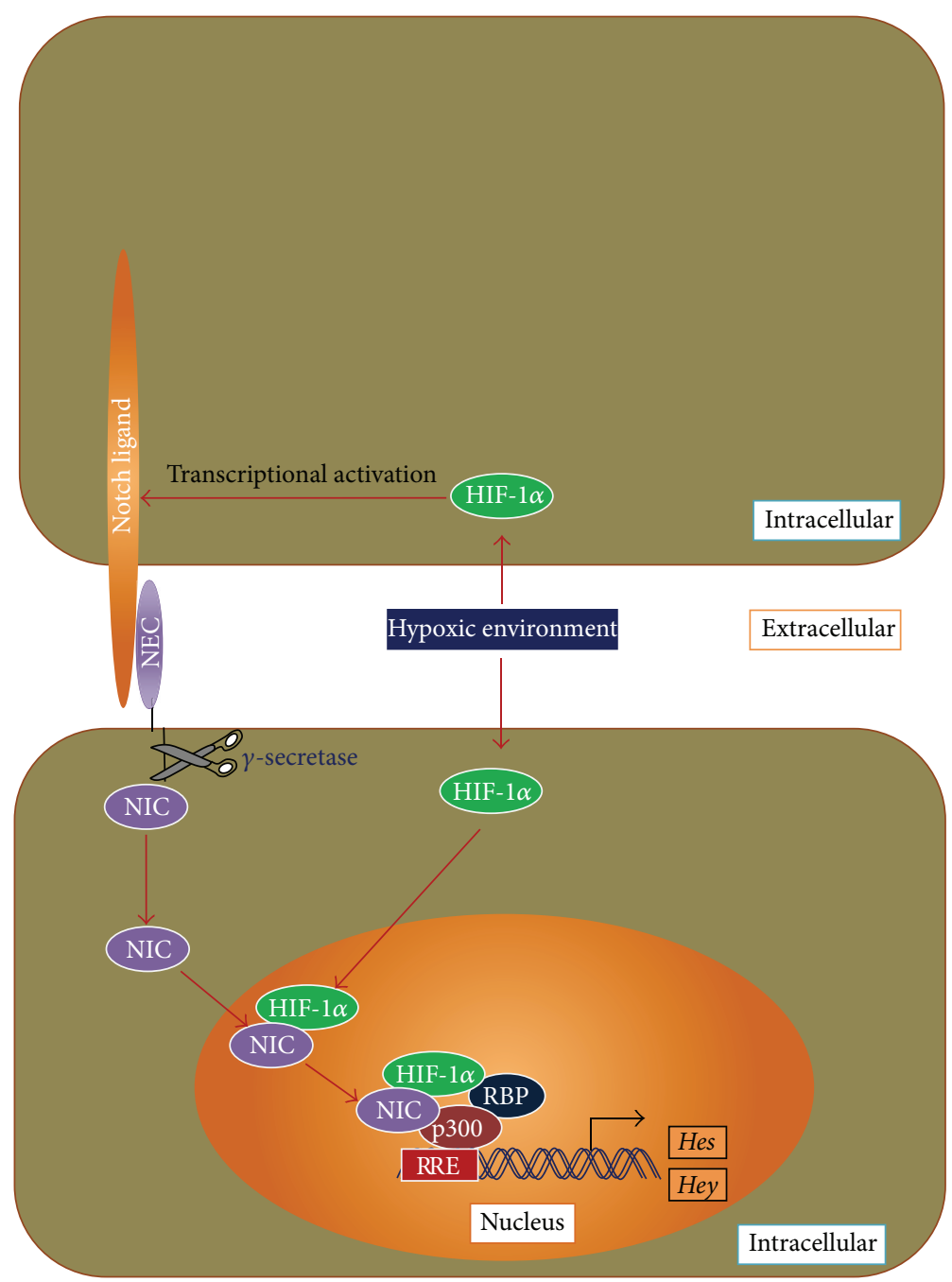

FIGURE 4: Crosstalk between hypoxia and notch signaling, and regulation of stem cell proliferative gene expression. HIF: hypoxia-inducible factor; NEC: notch extracellular domain; NIC: notch intracellular domain; RBP: recombination-signal binding protein. (Modified from Gustafsson et al., (2005) [34] and Sainson and Harris (2006) [136]; see text for details).

the conversion of pyruvate into acetyl CoA [131] inhibiting the enzymatic activity of pyruvate dehydrogenase (PDH) (Figure 3). This results in the reduction of mitochondrial $\mathrm{O}_{2}$ consumption, and as a consequence, the production of reactive oxygen species (ROS) is lowered $[132,133]$. In addition, HIF-1 $\alpha$ in a hypoxic condition causes the production of cytochrome $\mathrm{c}$ that also ensures optimum ATP production and cell integrity, by minimizing ROS [134].

4.3. Induction of Notch Target Genes by Hypoxia. The Notch signaling pathway is an important pathway that regulates the stem cells fate [135]. Crosstalk between hypoxia and activated Notch signaling (Figure 4) has been reported by several researchers $[34,136]$. In hypoxic conditions, HIF-1 $\alpha$ can regulate cell fate by activation of Notch down-stream genes (e.g., Hes and Hey) necessary to maintain proliferation of stem cells. During this crosstalk, in response to ligand presentation from neighboring cells, Notch receptors undergo proteolytic activation that is mediated by two proteases (tumour necrosis factor and $\gamma$-secretase). Due to the proteolytic activity, Notch intracellular domain (NIC) is released and translocated into the nucleus. There, NIC binds to HIF-1 $\alpha$ to build heterodimer which binds to recombination-signal binding protein-Jk (RBP-Jk), CBP/p300 proteins, and RBP-Jk response element (RRE) in the Notch target genes to activate them (e.g., Hes and Hey genes) $[34,136]$.

4.4. Upregulation of Chemokine Receptors by Hypoxia. The success of cell-based therapies highly depends upon the engraftment of the transplanted cells. The engraftment of the transplanted cells to the target organ is mediated through interaction between chemotactic factors (released by the organ) and their receptors on the surface of the transplanted cells. Though there are controversies over the expression of chemokine receptors and their migration towards target organs [137], in recent years, several articles have also reported that interaction between chemokines (SDF1, fractalkine), and their receptors (e.g., CXCR4, CXCR7, 


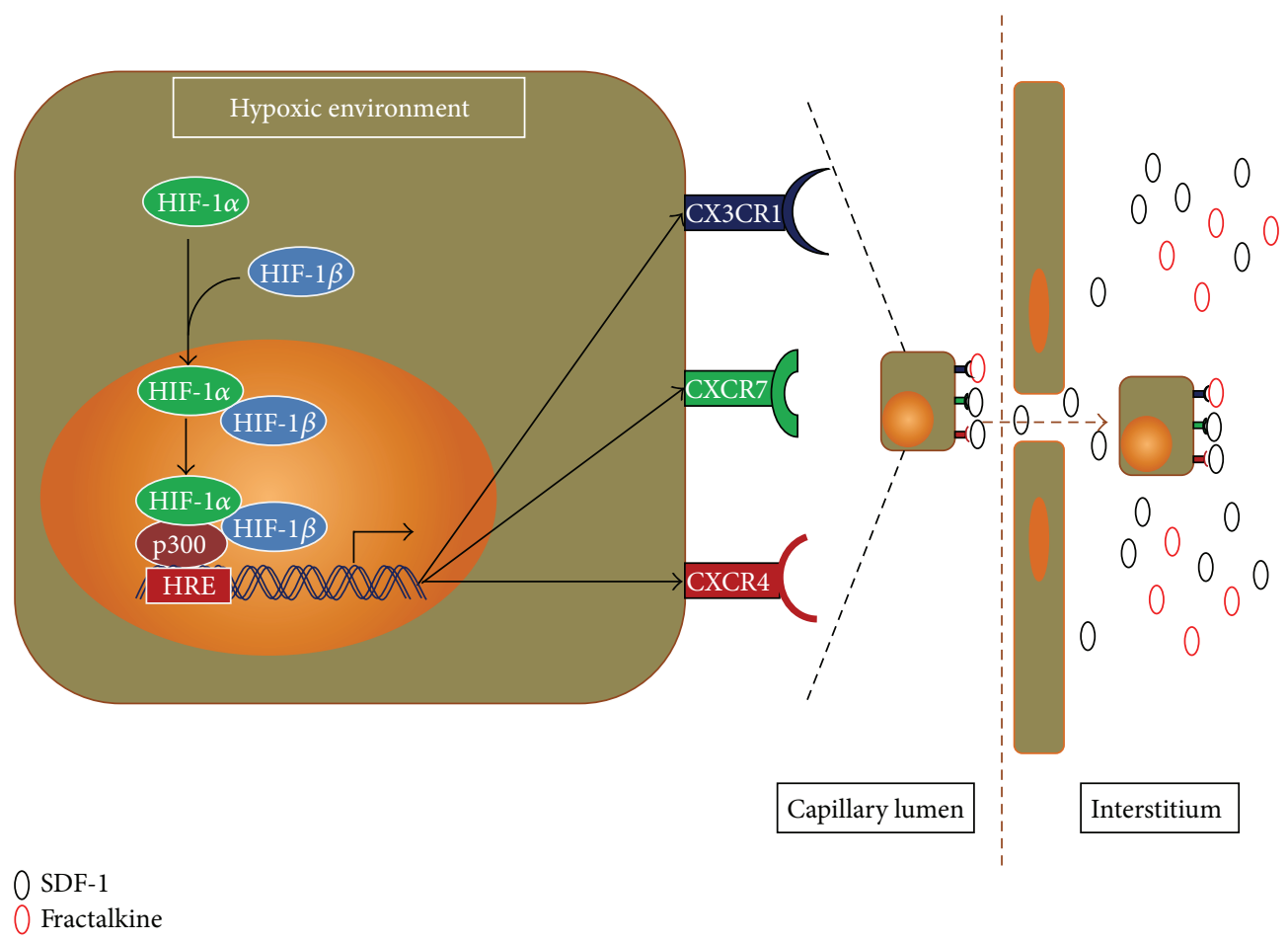

FIGURE 5: Upregulation of the expression of chemokine receptors by HIF-l $\alpha$ in hypoxic environment to facilitate target organ-specific chemotaxis. HIF: hypoxia-inducible factor; HRE: hypoxia-response element (see text for details).

and CX3CR1) play a vital role in chemotaxis, viability, and homing of MSCs both in vitro and in vivo $[113,138]$. Moreover, expression of chemokine receptors on MSCs increases in the presence of HIF-1 $\alpha$ [113]. The above information indicates that HIF1- $\alpha$ obtained stability in hypoxic condition prior to it being translocated into the nucleus, where it binds to HIF- $1 \beta$ to form the heterodimer. After that, the heterodimer binds to the gene-specific HRE associated with coactivators such as CBP/p300 [130] and upregulates the expression of chemokine receptors CXCR4, CXCR7, and CX3CR1. These chemokine receptors then respond to chemokines (e.g., SDF1 , fractalkine) secreted from diseased tissues or organs that finally facilitate the chemotaxis of the transplanted MSCs to the target site (Figure 5).

\section{Hypoxic Culture Conditions as a Solution for MSC-Based Regenerative Therapy}

The above discussions supported the positive role of hypoxic culture environments for MSCs and provided answers to solve problems related to cell-based therapies. In a hypoxic environment, HIF- $1 \alpha$ prevents the TCA cycle and results in lower ROS (Figure 3). Lower ROS generation resulted in slowing the rate of telomere shortening $[139,140]$, and as a consequence replicative senescence might be delayed. Moreover, a hypoxic environment upregulates the expression of Notch target genes (e.g., Hes and Hey genes), responsible for cell proliferation (Figure 4). Therefore, the higher proliferation rate along with more population doubling in hypoxic conditions $[37,38,92]$ may be due to the lowered ROS generation and overexpression of Notch target genes (e.g., Hes and Hey).

Maintaining genetic stability is another challenge during in vitro expansion of MSCs. Increased rates of aneuploidy, double-stranded DNA breakdown, and faster telomere shortening have been reported for MSCs cultured in ambient condition [37]. Gordon et al. (2012) reviewed the causes and consequences behind aneuploidy. They have defined defective spindle assembly checkpoint, centrosome amplification, and merotelic attachments as major causes behind aneuploidy [141]. Moreover, Wang et al. (2012) have described ROS as the causative factor of defective spindle assembly checkpoint, centrosome amplification and merotelic attachments [142]. ROS also acts in acceleration of telomere shortening and DNA breakdown $[143,144]$. In addition, correlation between telomere shortening and aneuploidy in embryonic and hepatocellular carcinoma cells has been reported in recently published articles $[145,146]$. The above discussion supports that higher ROS production due to the increased mitochondrial respiration during expansion of MSCs in ambient $\mathrm{O}_{2}$ concentration (Figure 3) might be the cause behind genetic instability in them. However, during hypoxia, cells go through anaerobic respiration, and as a result lower the ROS concentration within the cells (Figure 3). This might help in reducing the DNA damage, telomere shortening, and aneuploidy which in return may increase the biosafety of stem cell-based therapy.

Hypoxic culture conditions may also provide a solution for more efficient engraftment. Recently, it has been reported 
that early passaged mouse BM-MSCs showed better engraftment than late passaged mouse BM-MSCs in in vivo model [111]. Moreover, hypoxic preconditioned murine MSCs also showed enhanced skeletal muscle regeneration and improved blood flow and vascular formation compared to MSCs maintained in normoxic condition [112]. Furthermore, hypoxic conditions cause MSCs to grow faster [37] while maintaining a higher proportion of rapidly self-renewing cells [94]. In addition to that, a hypoxic environment increases the expression of chemokine receptors CXCR4, CXCR7, and CX3CR1 $[113,114]$, and they may facilitate tissue-specific trafficking of MSCs (Figure 5). From the above information, it can be anticipated that adequate numbers of MSCs with a higher fraction of rapidly self-renewing cells and highly expressed chemokine receptors on their surface can be obtained from the early passages of hypoxic cultures, and that MSCs might increase the efficiency of damaged-tissue-specific migration and engraftment following transplantation. Therefore, culturing MSCs in hypoxic conditions can also be considered as a solution for tissue-specific engraftment.

\section{Conclusion}

MSCs have tremendous potential in regenerative medicine. However, poor growth kinetics, genetic instability, and poor engraftment after transplantation are seen as drawbacks in their translation from bench side to bed side. The above information suggests hypoxic culture conditions $\left(2-5 \% \mathrm{O}_{2}\right.$ concentration) as a promising solution to overcome these problems. Tissue development and regeneration process solely depend upon the sequential steps of stem cell renewal, specialization, and assembly that are coordinated by the cascades of environmental factors in its niche, rather than with one single dominating factor. Thus, success in cellbased regenerative therapies requires a holistic view of stem cell regulation. Besides maintaining MSCs in physiological oxygen condition, there is a need to develop new techniques to analyze in vivo conditions of the stem cell niche, so that the appropriate in vitro modelling can yield novel information for niche-directed cell-based therapies.

\section{Conflict of Interests}

No competing financial interests exist.

\section{Acknowledgment}

The work is part of a project supported by the University of Malaya, High Impact Research-Ministry of Higher Education, Malaysia (UM.C/HIR/MOHE/DENT/01).

\section{References}

[1] D. T. Harris, "Non-haematological uses of cord blood stem cells," British Journal of Haematology, vol. 147, no. 2, pp. 177-184, 2009.

[2] J. Rehman, "Empowering self-renewal and differentiation: the role of mitochondria in stem cells," Journal of Molecular Medicine, vol. 88, no. 10, pp. 981-986, 2010.
[3] A. J. Wagers, “The stem cell niche in regenerative medicine," Cell Stem Cell, vol. 10, no. 4, pp. 362-369, 2012.

[4] M. Dominici, K. Le Blanc, I. Mueller et al., "Minimal criteria for defining multipotent mesenchymal stromal cells. The International Society for Cellular Therapy position statement," Cytotherapy, vol. 8, no. 4, pp. 315-317, 2006.

[5] V. Govindasamy, V. S. Ronald, A. N. Abdullah et al., "Differentiation of dental pulp stem cells into islet-like aggregates," Journal of Dental Research, vol. 90, no. 5, pp. 646-652, 2011.

[6] M. Sasaki, R. Abe, Y. Fujita, S. Ando, D. Inokuma, and H. Shimizu, "Mesenchymal stem cells are recruited into wounded skin and contribute to wound repair by transdifferentiation into multiple skin cell type," Journal of Immunology, vol. 180, no. 4, pp. 2581-2587, 2008.

[7] C. Toma, M. F. Pittenger, K. S. Cahill, B. J. Byrne, and P. D. Kessler, "Human mesenchymal stem cells differentiate to a cardiomyocyte phenotype in the adult murine heart," Circulation, vol. 105, no. 1, pp. 93-98, 2002.

[8] A. I. Caplan and J. E. Dennis, "Mesenchymal stem cells as trophic mediators," Journal of Cellular Biochemistry, vol. 98, no. 5, pp. 1076-1084, 2006.

[9] M. Zhang, N. Mal, M. Kiedrowski et al., "SDF-1 expression by mesenchymal stem cells results in trophic support of cardiac myocytes after myocardial infarction," The FASEB Journal, vol. 21, no. 12, pp. 3197-3207, 2007.

[10] S. Aggarwal and M. F. Pittenger, "Human mesenchymal stem cells modulate allogeneic immune cell responses," Blood, vol. 105, no. 4, pp. 1815-1822, 2005.

[11] X. Chen, M. A. Armstrong, and G. Li, "Mesenchymal stem cells in immunoregulation," Immunology and Cell Biology, vol. 84, no. 5, pp. 413-421, 2006.

[12] A. J. Nauta and W. E. Fibbe, "Immunomodulatory properties of mesenchymal stromal cells," Blood, vol. 110, no. 10, pp. 34993506, 2007.

[13] T. P. Martens, F. See, M. D. Schuster et al., "Mesenchymal lineage precursor cells induce vascular network formation in ischemic myocardium," Nature Clinical Practice Cardiovascular Medicine, vol. 3, no. 1, pp. S18-S22, 2006.

[14] A. Erices, P. Conget, and J. J. Minguell, "Mesenchymal progenitor cells in human umbilical cord blood," British Journal of Haematology, vol. 109, no. 1, pp. 235-242, 2000.

[15] V. Govindasamy, A. N. Abdullah, V. S. Ronald et al., "Inherent differential propensity of dental pulp stem cells derived from human deciduous and permanent teeth," Journal of Endodontics, vol. 36, no. 9, pp. 1504-1515, 2010.

[16] P. Lund, L. Pilgaard, M. Duroux, T. Fink, and V. Zachar, "Effect of growth media and serum replacements on the proliferation and differentiation of adipose-derived stem cells," Cytotherapy, vol. 11, no. 2, pp. 189-197, 2009.

[17] S. Shi and S. Gronthos, "Perivascular niche of postnatal mesenchymal stem cells in human bone marrow and dental pulp," Journal of Bone and Mineral Research, vol. 18, no. 4, pp. 696-704, 2003.

[18] T. Kosztowski, H. A. Zaidi, and A. Quiñones-Hinojosa, "Applications of neural and mesenchymal stem cells in the treatment of gliomas," Expert Review of Anticancer Therapy, vol. 9, no. 5, pp. 597-612, 2009.

[19] Y. Miyahara, N. Nagaya, M. Kataoka et al., "Monolayered mesenchymal stem cells repair scarred myocardium after myocardial infarction," Nature Medicine, vol. 12, no. 4, pp. 459-465, 2006. 
[20] S. M. Richardson, J. A. Hoyland, R. Mobasheri, C. Csaki, M. Shakibaei, and A. Mobasheri, "Mesenchymal stem cells in regenerative medicine: opportunities and challenges for articular cartilage and intervertebral disc tissue engineering," Journal of Cellular Physiology, vol. 222, no. 1, pp. 23-32, 2010.

[21] G. Siegel, R. Schäfer, and F. Dazzi, "The immunosuppressive properties of mesenchymal stem cells," Transplantation, vol. 87, no. 9, pp. S45-S49, 2009.

[22] L. Aust, B. Devlin, S. J. Foster et al., "Yield of human adiposederived adult stem cells from liposuction aspirates," Cytother$a p y$, vol. 6, no. 1, pp. 7-14, 2004.

[23] M. F. Pittenger, A. M. Mackay, S. C. Beck et al., "Multilineage potential of adult human mesenchymal stem cells," Science, vol. 284, no. 5411, pp. 143-147, 1999.

[24] M. Faustini, M. Bucco, T. Chlapanidas et al., "Nonexpanded mesenchymal stem cells for regenerative medicine: yield in stromal vascular fraction from adipose tissues," Tissue Engineering C, vol. 16, no. 6, pp. 1515-1521, 2010.

[25] P. Connick, M. Kolappan, R. Patani et al., "The mesenchymal stem cells in multiple sclerosis (MSCIMS) trial protocol and baseline cohort characteristics: an open-label pre-test: post-test study with blinded outcome assessments," Trials, vol. 12, article 62, 2011

[26] B. Trachtenberg, D. L. Velazquez, A. R. Williams et al., "Rationale and design of the transendocardial injection of autologous human cells (bone marrow or mesenchymal) in chronic ischemic left ventricular dysfunction and heart failure secondary to myocardial infarction (TAC-HFT) trial: a randomized, double-blind, placebo-controlled study of safety and efficacy," American Heart Journal, vol. 161, no. 3, pp. 487-493, 2011.

[27] J. M. Hare, J. E. Fishman, G. Gerstenblith et al., "Comparison of allogeneic vs autologous bone marrow-derived mesenchymal stem cells delivered by transendocardial injection in patients with ischemic cardiomyopathy: the POSEIDON randomized trial," Journal of the American Medical Association, vol. 308, no. 22, pp. 2369-2379, 2012.

[28] S. Kirana, B. Stratmann, C. Prante et al., "Autologous stem cell therapy in the treatment of limb ischaemia induced chronic tissue ulcers of diabetic foot patients," International Journal of Clinical Practice, vol. 66, no. 4, pp. 384-393, 2012.

[29] J. Tan, W. Wu, X. Xu et al., "Induction therapy with autologous mesenchymal stem cells in living-related kidney transplants: a randomized controlled trial," Journal of the American Medical Association, vol. 307, no. 11, pp. 1169-1177, 2012.

[30] R. S. N. Tewarie, A. Hurtado, R. H. Bartels, A. Grotenhuis, and M. Oudega, "Stem cell-based therapies for spinal cord injury," Journal of Spinal Cord Medicine, vol. 32, no. 2, pp. 105-114, 2009.

[31] O. Ringdén, M. Uzunel, I. Rasmusson et al., "Mesenchymal stem cells for treatment of therapy-resistant graft-versus-host disease," Transplantation, vol. 81, no. 10, pp. 1390-1397, 2006.

[32] K. Le Blanc, F. Frassoni, L. Ball et al., "Mesenchymal stem cells for treatment of steroid-resistant, severe, acute graft-versushost disease: a phase II study," The Lancet, vol. 371, no. 9624, pp. 1579-1586, 2008.

[33] M. Mohamadnejad, B. Pournasr, M. Bagheri et al., "Transplantation of allogeneic bone marrow mesenchymal stromal cellderived hepatocyte-like cells in homozygous familial hypercholesterolemia," Cytotherapy, vol. 12, no. 4, pp. 566-568, 2010.

[34] M. V. Gustafsson, X. Zheng, T. Pereira et al., "Hypoxia requires Notch signaling to maintain the undifferentiated cell state," Developmental Cell, vol. 9, no. 5, pp. 617-628, 2005.
[35] E. S. Antoniou, S. Sund, E. N. Homsi, L. F. Challenger, and P. Rameshwar, "A theoretical simulation of hematopoietic stem cells during oxygen fluctuations: prediction of bone marrow responses during hemorrhagic shock," Shock, vol. 22, no. 5, pp. 415-422, 2004.

[36] D. C. Chow, L. A. Wenning, W. M. Miller, and E. T. Papoutsakis, "Modeling $\mathrm{pO}_{2}$ distributions in the bone marrow hematopoietic compartment. II. Modified Kroghian models," Biophysical Journal, vol. 81, no. 2, pp. 685-696, 2001.

[37] J. C. Estrada, C. Albo, A. Benguría et al., "Culture of human mesenchymal stem cells at low oxygen tension improves growth and genetic stability by activating glycolysis," Cell Death and Differentiation, vol. 19, no. 5, pp. 743-755, 2012.

[38] C. Fehrer, R. Brunauer, G. Laschober et al., "Reduced oxygen tension attenuates differentiation capacity of human mesenchymal stem cells and prolongs their lifespan," Aging Cell, vol. 6, no. 6, pp. 745-757, 2007.

[39] V. Schächinger, S. Erbs, A. Elsässer et al., "Intracoronary bone marrow-derived progenitor cells in acute myocardial infarction," New England Journal of Medicine, vol. 355, no. 12, pp. 12101221, 2006.

[40] M. C. Simon and B. Keith, "The role of oxygen availability in embryonic development and stem cell function," Nature Reviews Molecular Cell Biology, vol. 9, no. 4, pp. 285-296, 2008.

[41] G. Vunjak-Novakovic and D. T. Scadden, "Biomimetic platforms for human stem cell research," Cell Stem Cell, vol. 8, no. 3, pp. 252-261, 2011.

[42] R. Schofield, "The relationship between the spleen colonyforming cell and the haemopoietic stem cell. A hypothesis," Blood Cells, vol. 4, no. 1-2, pp. 7-25, 1978.

[43] S. K. Nilsson, H. M. Johnston, and J. A. Coverdale, "Spatial localization of transplanted hemopoietic stem cells: inferences for the localization of stem cell niches," Blood, vol. 97, no. 8, pp. 2293-2299, 2001.

[44] A. Quiñones-Hinojosa, N. Sanai, M. Soriano-Navarro et al., "Cellular composition and cytoarchitecture of the adult human subventricular zone: a niche of neural stem cells," The Journal of Comparative Neurology, vol. 494, no. 3, pp. 415-434, 2005.

[45] T. Xie and A. C. Spradling, "decapentaplegic is essential for the maintenance and division of germline stem cells in the Drosophila ovary," Cell, vol. 94, no. 2, pp. 251-260, 1998.

[46] L. Buravkova, E. Andreeva, J. Rylova, and A. Grigoriev, "Resistance of multipotent mesenchymal atromal cells to anoxia in vitro," in Anoxia, pp. 61-80, InTech, Rijeka, Croatia, 2011.

[47] D. L. Jones and A. J. Wagers, "No place like home: anatomy and function of the stem cell niche," Nature Reviews Molecular Cell Biology, vol. 9, no. 1, pp. 11-21, 2008.

[48] T. Yin and L. Li, "The stem cell niches in bone," Journal of Clinical Investigation, vol. 116, no. 5, pp. 1195-1201, 2006.

[49] B. Fischer and B. D. Bavister, "Oxygen tension in the oviduct and uterus of rhesus monkeys, hamsters and rabbits," Journal of Reproduction and Fertility, vol. 99, no. 2, pp. 673-679, 1993.

[50] G. A. Yedwab, G. Paz, T. Z. Homonnal, M. David, and P. Kraicer, "The temperature, $\mathrm{pH}$, and partial pressure of oxygen in the cervix and uterus of women and uterus of rats during the cycle," Fertility and Sterility, vol. 27, no. 3, pp. 304-309, 1976.

[51] J. Folkman, P. Hahnfeldt, and L. Hlatky, "Cancer: looking outside the genome," Nature Reviews Molecular Cell Biology, vol. 1, no. 1, pp. 76-79, 2000.

[52] R. A. Gatenby and R. J. Gillies, "Why do cancers have high aerobic glycolysis?" Nature Reviews Cancer, vol. 4, no. 11, pp. 891-899, 2004. 
[53] M. Gassmann, J. Fandrey, S. Bichet et al., "Oxygen supply and oxygen-dependent gene expression in differentiating embryonic stem cells," Proceedings of the National Academy of Sciences of the United States of America, vol. 93, no. 7, pp. 2867-2872, 1996.

[54] E. Jauniaux, A. L. Watson, J. Hempstock, Y.-P. Bao, J. N. Skepper, and G. J. Burton, "Onset of maternal arterial blood flow and placental oxidative stress: a possible factor in human early pregnancy failure," American Journal of Pathology, vol. 157, no. 6, pp. 2111-2122, 2000.

[55] F. Rodesch, P. Simon, C. Donner, and E. Jauniaux, "Oxygen measurements in endometrial and trophoblastic tissues during early pregnancy," Obstetrics and Gynecology, vol. 80, no. 2, pp. 283-285, 1992.

[56] K. Takahashi, K. Tanabe, M. Ohnuki et al., "Induction of pluripotent stem cells from adult human fibroblasts by defined factors," Cell, vol. 131, no. 5, pp. 861-872, 2007.

[57] Y. Yoshida, K. Takahashi, K. Okita, T. Ichisaka, and S. Yamanaka, "Hypoxia enhances the generation of induced pluripotent stem cells," Cell Stem Cell, vol. 5, no. 3, pp. 237-241, 2009.

[58] G. Chen, D. R. Gulbranson, Z. Hou et al., "Chemically defined conditions for human iPSC derivation and culture," Nature Methods, vol. 8, no. 5, pp. 424-429, 2011.

[59] M. Crisan, S. Yap, L. Casteilla et al., "A perivascular origin for mesenchymal stem cells in multiple human organs," Cell Stem Cell, vol. 3, no. 3, pp. 301-313, 2008.

[60] A. C. W. Zannettino, S. Paton, A. Arthur et al., "Multipotential human adipose-derived stromal stem cells exhibit a perivascular phenotype in vitro and in vivo," Journal of Cellular Physiology, vol. 214, no. 2, pp. 413-421, 2008.

[61] J. W. Snow, N. Abraham, M. C. Ma, N. W. Abbey, B. Herndier, and M. A. Goldsmith, "Oxygen saturation in the bone marrow of healthy volunteers," Blood, vol. 99, no. 1, p. 394, 2002.

[62] M. Pasarica, O. R. Sereda, L. M. Redman et al., "Reduced adipose tissue oxygenation in human obesity evidence for rarefaction, macrophage chemotaxis, and inflammation without an angiogenic response," Diabetes, vol. 58, no. 3, pp. 718-725, 2009.

[63] F. R. Sharp and M. Bernaudin, "HIF1 and oxygen sensing in the brain," Nature Reviews Neuroscience, vol. 5, no. 6, pp. 437-448, 2004.

[64] Z. Ivanovic, "Hypoxia or in situ normoxia: the stem cell paradigm," Journal of Cellular Physiology, vol. 219, no. 2, pp. 271275, 2009.

[65] J. M. Wild, S. Fichele, N. Woodhouse, M. N. J. Paley, L. Kasuboski, and E. J. R. Van Beek, "3D volume-localized $\mathrm{pO}_{2}$ measurement in the human lung with $3 \mathrm{He}$ MRI," Magnetic Resonance in Medicine, vol. 53, no. 5, pp. 1055-1064, 2005.

[66] B. A. McKinley and B. D. Butler, "Comparison of skeletal muscle $\mathrm{PO}_{2}, \mathrm{PCO}_{2}$, and $\mathrm{pH}$ with gastric tonometric $\mathrm{PCO}_{2}$ and $\mathrm{pH}$ in hemorrhagic shock," Critical Care Medicine, vol. 27, no. 9, pp. 1869-1877, 1999.

[67] K. Jungermann and T. Kietzmann, "Role of oxygen in the zonation of carbohydrate metabolism and gene expression in liver," Kidney International, vol. 51, no. 2, pp. 402-412, 1997.

[68] W. J. Welch, H. Baumgärtl, D. Lübbers, and C. S. Wilcox, "Nephron $\mathrm{pO}_{2}$ and renal oxygen usage in the hypertensive rat kidney," Kidney International, vol. 59, no. 1, pp. 230-237, 2001.

[69] E. G. Mik, T. G. Van Leeuwen, N. J. Raat, and C. Ince, "Quantitative determination of localized tissue oxygen concentration in vivo by two-photon excitation phosphorescence lifetime measurements," Journal of Applied Physiology, vol. 97, no. 5, pp. 1962-1969, 2004.

[70] S. Roy, S. Khanna, W. A. Wallace et al., "Characterization of perceived hyperoxia in isolated primary cardiac fibroblasts and in the reoxygenated heart," Journal of Biological Chemistry, vol. 278, no. 47, pp. 47129-47135, 2003.

[71] M. Erecińska and I. A. Silver, "Tissue oxygen tension and brain sensitivity to hypoxia," Respiration Physiology, vol. 128, no. 3, pp. 263-276, 2001.

[72] J. C. Hemphill III, W. S. Smith, D. C. Sonne, D. Morabito, and G. T. Manley, "Relationship between brain tissue oxygen tension and CT perfusion: feasibility and initial results," American Journal of Neuroradiology, vol. 26, no. 5, pp. 1095-1100, 2005.

[73] D. M. Panchision, "The role of oxygen in regulating neural stem cells in development and disease," Journal of cellular physiology, vol. 220, no. 3, pp. 562-568, 2009.

[74] D. G. Buerk, R. D. Shonat, C. E. Riva, and S. D. Cranstoun, " $\mathrm{O}_{2}$ gradients and countercurrent exchange in the cat vitreous humor near retinal arterioles and venules," Microvascular Research, vol. 45, no. 2, pp. 134-148, 1993.

[75] D.-Y. Yu and S. J. Cringle, "Retinal degeneration and local oxygen metabolism," Experimental Eye Research, vol. 80, no. 6, pp. 745-751, 2005.

[76] P. Eliasson and J.-I. Jönsson, “The hematopoietic stem cell niche: low in oxygen but a nice place to be," Journal of Cellular Physiology, vol. 222, no. 1, pp. 17-22, 2010.

[77] A. Mohyeldin, T. Garzón-Muvdi, and A. Quiñones-Hinojosa, "Oxygen in stem cell biology: a critical component of the stem cell niche," Cell Stem Cell, vol. 7, no. 2, pp. 150-161, 2010.

[78] A. J. Becker, E. A. McCulloch, and J. E. Till, "Cytological demonstration of the clonal nature of spleen colonies derived from transplanted mouse marrow cells," Nature, vol. 197, no. 4866, pp. 452-454, 1963.

[79] L. Siminovitch, E. A. McCulloch, and J. E. Till, "The distribution of colony-forming cells among spleen colonies," Journal of Cellular and Comparative Physiology, vol. 62, no. 3, pp. 327-336, 2005.

[80] M. Honczarenko, Y. Le, M. Swierkowski, I. Ghiran, A. M. Glodek, and L. E. Silberstein, "Human bone marrow stromal cells express a distinct set of biologically functional chemokine receptors," Stem Cells, vol. 24, no. 4, pp. 1030-1041, 2006.

[81] E. J. Kim, N. Kim, and S. G. Cho, "The potential use of mesenchymal stem cells in hematopoietic stem cell transplantation," Experimental \& Molecular Medicine, vol. 45, no. 1, p. e2, 2013.

[82] N. Barker, J. H. Van Es, J. Kuipers et al., "Identification of stem cells in small intestine and colon by marker gene Lgr5," Nature, vol. 449, no. 7165, pp. 1003-1007, 2007.

[83] F. Relaix, D. Rocancourt, A. Mansouri, and M. Buckingham, "A Pax3/Pax7-dependent population of skeletal muscle progenitor cells," Nature, vol. 435, no. 7044, pp. 948-953, 2005.

[84] X. Yan and D. M. Owens, "The skin: a home to multiple classes of epithelial progenitor cells," Stem Cell Reviews, vol. 4, no. 2, pp. 113-118, 2008.

[85] H.-J. Buhrin, V. L. Battula, S. Treml, B. Schewe, L. Kanz, and W. Vogel, "Novel markers for the prospective isolation of human MSC," Annals of the New York Academy of Sciences, vol. 1106, pp. 262-271, 2007.

[86] L. G. van der Flier and H. Clevers, "Stem cells, self-renewal, and differentiation in the intestinal epithelium," Annual Review of Physiology, vol. 71, pp. 241-260, 2009. 
[87] H. Zheng, H. Ying, R. Wiedemeyer et al., "PLAGL2 regulates Wnt signaling to impede differentiation in neural stem cells and gliomas," Cancer Cell, vol. 17, no. 5, pp. 497-509, 2010.

[88] D. T. Scadden, "The stem-cell niche as an entity of action," Nature, vol. 441, no. 7097, pp. 1075-1079, 2006.

[89] S.-C. Hung, "Effects of hypoxic culture on bone marrow mesenchymal stem cells: from bench to bedside," Formosan Journal of Surgery, vol. 46, no. 2, pp. 35-38, 2013.

[90] L. Basciano, C. Nemos, B. Foliguet et al., "Long term culture of mesenchymal stem cells in hypoxia promotes a genetic program maintaining their undifferentiated and multipotent status," BMC Cell Biology, vol. 12, article 12, 2011.

[91] W. L. Grayson, F. Zhao, B. Bunnell, and T. Ma, "Hypoxia enhances proliferation and tissue formation of human mesenchymal stem cells," Biochemical and Biophysical Research Communications, vol. 358, no. 3, pp. 948-953, 2007.

[92] U. Nekanti, S. Dastidar, P. Venugopal, S. Totey, and M. Ta, "Increased proliferation and analysis of differential gene expression in human Wharton's jelly-derived mesenchymal stromal cells under hypoxia," International Journal of Biological Sciences, vol. 6, no. 5, pp. 499-512, 2010.

[93] E. M. Weijers, L. J. Van Den Broek, T. Waaijman, V. W. M. Van Hinsbergh, S. Gibbs, and P. Koolwijk, "The influence of hypoxia and fibrinogen variants on the expansion and differentiation of adipose tissue-derived mesenchymal stem cells," Tissue Engineering A, vol. 17, no. 21-22, pp. 2675-2685, 2011.

[94] M. M. Saller, W. C. Prall, D. Docheva et al., "Increased stemness and migration of human mesenchymal stem cells in hypoxia is associated with altered integrin expression," Biochemical and Biophysical Research Communications, vol. 423, no. 2, pp. 379385, 2012.

[95] C. Holzwarth, M. Vaegler, F. Gieseke et al., "Low physiologic oxygen tensions reduce proliferation and differentiation of human multipotent mesenchymal stromal cells," BMC Cell Biology, vol. 11, article 11, 2010.

[96] L. F. Raheja, D. C. Genetos, and C. E. Yellowley, "The effect of oxygen tension on the long-term osteogenic differentiation and MMP/TIMP expression of human mesenchymal stem cells," Cells Tissues Organs, vol. 191, no. 3, pp. 175-184, 2010.

[97] Y. López, K. Seshareddy, E. Trevino, J. Cox, and M. L. Weiss, "Evaluating the impact of oxygen concentration and plating density on human wharton's jelly-derived mesenchymal stromal cells," Open Tissue Engineering and Regenerative Medicine Journal, vol. 4, no. 1, pp. 82-94, 2011.

[98] M. G. Valorani, E. Montelatici, A. Germani et al., "Pre-culturing human adipose tissue mesenchymal stem cells under hypoxia increases their adipogenic and osteogenic differentiation potentials," Cell Proliferation, vol. 45, no. 3, pp. 225-238, 2012.

[99] S.-P. Hung, J. H. Ho, Y.-R. V. Shih, T. Lo, and O. K. Lee, "Hypoxia promotes proliferation and osteogenic differentiation potentials of human mesenchymal stem cells," Journal of Orthopaedic Research, vol. 30, no. 2, pp. 260-266, 2012.

[100] D.-C. Yang, M.-H. Yang, C.-C. Tsai, T.-F. Huang, Y.-H. Chen, and S.-C. Hung, "Hypoxia inhibits osteogenesis in human mesenchymal stem cells through direct regulation of RUNX2 by TWIST," PLoS ONE, vol. 6, no. 9, Article ID e23965, 2011.

[101] N. P. Bochkov, M. S. Vinogradova, I. K. Volkov, E. S. Voronina, and N. P. Kuleshov, "Statistical analysis of clone formation in cultures of human stem cells," Bulletin of Experimental Biology and Medicine, vol. 151, no. 4, pp. 498-501, 2011.
[102] K. Tarte, J. Gaillard, J.-J. Lataillade et al., "Clinical-grade production of human mesenchymal stromal cells: occurrence of aneuploidy without transformation," Blood, vol. 115, no. 8, pp. 1549-1553, 2010.

[103] B. A. Weaver and D. W. Cleveland, "Does aneuploidy cause cancer?" Current Opinion in Cell Biology, vol. 18, no. 6, pp. 658667, 2006.

[104] M. Ozery-Flato, C. Linhart, L. Trakhtenbrot, S. Izraeli, and R. Shamir, "Large-scale analysis of chromosomal aberrations in cancer karyotypes reveals two distinct paths to aneuploidy," Genome Biology, vol. 12, no. 6, article R61, 2011.

[105] E. Chavakis, M. Koyanagi, and S. Dimmeler, "Enhancing the outcome of cell therapy for cardiac repair: progress from bench to bedside and back," Circulation, vol. 121, no. 2, pp. 325-335, 2010.

[106] A. Abdel-Latif, R. Bolli, I. M. Tleyjeh et al., "Adult bone marrowderived cells for cardiac repair: a systematic review and metaanalysis," Archives of Internal Medicine, vol. 167, no. 10, pp. 989997, 2007.

[107] M. J. Lipinski, G. G. L. Biondi-Zoccai, A. Abbate et al., "Impact of intracoronary cell therapy on left ventricular function in the setting of acute myocardial infarction: a collaborative systematic review and meta-analysis of controlled clinical trials," Journal of the American College of Cardiology, vol. 50, no. 18, pp. 1761-1767, 2007.

[108] G. Vassilopoulos, P.-R. Wang, and D. W. Russell, "Transplanted bone marrow regenerates liver by cell fusion," Nature, vol. 422, no. 6934, pp. 901-904, 2003.

[109] A. J. Wagers and I. L. Weissman, "Plasticity of adult stem cells," Cell, vol. 116, no. 5, pp. 639-648, 2004.

[110] X. Wang, H. Willenbring, Y. Akkari et al., "Cell fusion is the principal source of bone-marrow-derived hepatocytes," Nature, vol. 422, no. 6934, pp. 897-901, 2003.

[111] J. Jin, Y. Zhao, X. Tan, C. Guo, Z. Yang, and D. Miao, "An improved transplantation strategy for mouse mesenchymal stem cells in an acute myocardial infarction model," PLOS ONE, vol. 6, no. 6, Article ID e21005, 2011.

[112] L. Leroux, B. Descamps, N. F. Tojais et al., "Hypoxia preconditioned mesenchymal stem cells improve vascular and skeletal muscle fiber regeneration after ischemia through a wnt4-dependent pathway," Molecular Therapy, vol. 18, no. 8, pp. 1545-1552, 2010.

[113] H. Liu, S. Liu, Y. Li et al., "The role of SDF-1-CXCR4/CXCR7 axis in the therapeutic effects of hypoxia-preconditioned mesenchymal stem cells for renal ischemia/reperfusion injury," PloS ONE, vol. 7, no. 4, Article ID e34608, 2012.

[114] S.-C. Hung, R. R. Pochampally, S.-C. Hsu et al., "Short-term exposure of multipotent stromal cells to low oxygen increases their expression of CX3CR1 and CXCR4 and their engraftment in vivo," PLoS ONE, vol. 2, no. 5, article e416, 2007.

[115] C.-C. Tsai, T.-L. Yew, D.-C. Yang, W.-H. Huang, and S.-C. Hung, "Benefits of hypoxic culture on bone marrow multipotent stromal cells," American Journal of Blood Research, vol. 2, no. 3, p. 148, 2012.

[116] R. F. Wynn, C. A. Hart, C. Corradi-Perini et al., "A small proportion of mesenchymal stem cells strongly expresses functionally active CXCR4 receptor capable of promoting migration to bone marrow," Blood, vol. 104, no. 9, pp. 2643-2645, 2004.

[117] V. Sordi, M. L. Malosio, F. Marchesi et al., "Bone marrow mesenchymal stem cells express a restricted set of functionally active chemokine receptors capable of promoting migration to pancreatic islets," Blood, vol. 106, no. 2, pp. 419-427, 2005. 
[118] C.-H. Song, O. Honmou, H. Furuoka, and M. Horiuchi, "Identification of chemoattractive factors involved in the migration of bone marrow-derived mesenchymal stem cells to brain lesions caused by prions," Journal of Virology, vol. 85, no. 21, pp. 1106911078, 2011.

[119] Q. Lin, Y. Kim, R. M. Alarcon, and Z. Yun, "Oxygen and cell fate decisions," Gene Regulation and Systems Biology, vol. 2008, no. 2, pp. 43-51, 2008.

[120] N. S. Kenneth and S. Rocha, "Regulation of gene expression by hypoxia," Biochemical Journal, vol. 414, no. 1, pp. 19-29, 2008.

[121] K. Stamati, V. Mudera, and U. Cheema, "Evolution of oxygen utilization in multicellular organisms and implications for cell signalling in tissue engineering," Journal of Tissue Engineering, vol. 2, no. 1, 2011.

[122] G.-H. Fong, "Mechanisms of adaptive angiogenesis to tissue hypoxia," Angiogenesis, vol. 11, no. 2, pp. 121-140, 2008.

[123] G. L. Wang, B.-H. Jiang, E. A. Rue, and G. L. Semenza, "Hypoxia-inducible factor 1 is a basic-helix-loop-helix-PAS heterodimer regulated by cellular $\mathrm{O}_{2}$ tension," Proceedings of the National Academy of Sciences of the United States of America, vol. 92, no. 12, pp. 5510-5514, 1995.

[124] A. Weidemann and R. S. Johnson, "Biology of HIF-1 $\alpha$," Cell Death and Differentiation, vol. 15, no. 4, pp. 621-627, 2008.

[125] P. Jaakkola, D. R. Mole, Y.-M. Tian et al., "Targeting of HIF- $\alpha$ to the von Hippel-Lindau ubiquitylation complex by $\mathrm{O}_{2}$-regulated prolyl hydroxylation," Science, vol. 292, no. 5516, pp. 468-472, 2001.

[126] W.-C. Hon, M. I. Wilson, K. Harlos et al., "Structural basis for the recognition of hydroxyproline in HIF- $1 \alpha$ by pVHL," Nature, vol. 417, no. 6892, pp. 975-978, 2002.

[127] E. Metzen, U. Berchner-Pfannschmidt, P. Stengel et al., "Intracellular localisation of human HIF-1 $\alpha$ hydroxylases: implications for oxygen sensing," Journal of Cell Science, vol. 116, no. 7, pp. 1319-1326, 2003

[128] M. Ivan, K. Kondo, H. Yang et al., "HIF $\alpha$ targeted for VHLmediated destruction by proline hydroxylation: implications for $\mathrm{O}_{2}$ sensing," Science, vol. 292, no. 5516, pp. 464-468, 2001.

[129] P. H. Maxwell, M. S. Wlesener, G.-W. Chang et al., "The tumour suppressor protein VHL targets hypoxia-inducible factors for oxygen-dependent proteolysis," Nature, vol. 399, no. 6733, pp. 271-275, 1999.

[130] M. C. Brahimi-Horn and J. Pouysségur, "Oxygen, a source of life and stress," FEBS Letters, vol. 581, no. 19, pp. 3582-3591, 2007.

[131] A. Lavrentieva, I. Majore, C. Kasper, and R. Hass, "Effects of hypoxic culture conditions on umbilical cord-derived human mesenchymal stem cells," Cell Communication and Signaling, vol. 8, p. 18, 2010.

[132] J.-W. Kim, I. Tchernyshyov, G. L. Semenza, and C. V. Dang, "HIF-1-mediated expression of pyruvate dehydrogenase kinase: a metabolic switch required for cellular adaptation to hypoxia," Cell Metabolism, vol. 3, no. 3, pp. 177-185, 2006.

[133] G. L. Semenza, "Regulation of oxygen homeostasis by hypoxiaInducible factor 1," Physiology, vol. 24, no. 2, pp. 97-106, 2009.

[134] V. G. A. Arciuch, M. E. Elguero, J. J. Poderoso, and M. C. Carreras, "Mitochondrial regulation of cell cycle and proliferation," Antioxidants and Redox Signaling, vol. 16, no. 10, pp. 1150-1180, 2012.

[135] F. Schweisguth, "Regulation of notch signaling activity," Current Biology, vol. 14, no. 3, pp. R129-R138, 2004.

[136] R. C. Sainson and A. L. Harris, "Hypoxia-regulated differentiation: let's step it up a Notch," Trends in Molecular Medicine, vol. 12, no. 4, pp. 141-143, 2006.
[137] A. L. Ponte, E. Marais, N. Gallay et al., "The in vitro migration capacity of human bone marrow mesenchymal stem cells: comparison of chemokine and growth factor chemotactic activities," Stem Cells, vol. 25, no. 7, pp. 1737-1745, 2007.

[138] M. Shi, J. Li, L. Liao et al., "Regulation of CXCR4 expression in human mesenchymal stem cells by cytokine treatment: role in homing efficiency in NOD/SCID mice," Haematologica, vol. 92, no. 7, pp. 897-904, 2007.

[139] A. G. Bodnar, M. Ouellette, M. Frolkis et al., "Extension of lifespan by introduction of telomerase into normal human cells," Science, vol. 279, no. 5349, pp. 349-352, 1998.

[140] T. Richter and T. V. Zglinicki, "A continuous correlation between oxidative stress and telomere shortening in fibroblasts," Experimental Gerontology, vol. 42, no. 11, pp. 1039-1042, 2007.

[141] D. J. Gordon, B. Resio, and D. Pellman, "Causes and consequences of aneuploidy in cancer," Nature Reviews Genetics, vol. 13, no. 3, pp. 189-203, 2012.

[142] C. Y. Wang, L. N. Liu, and Z. B. Zhao, "The role of ROS toxicity in spontaneous aneuploidy in cultured cells," Tissue and Cell, vol. 45, no. 1, pp. 47-53, 2012.

[143] A. Barzilai and K.-I. Yamamoto, "DNA damage responses to oxidative stress," DNA Repair, vol. 3, no. 8-9, pp. 1109-1115, 2004.

[144] L. M. Guachalla and K. L. Rudolph, "ROS induced DNA damage and checkpoint responses: influences on aging?" Cell Cycle, vol. 9, no. 20, pp. 4058-4060, 2010.

[145] N. R. Treff, J. Su, D. Taylor, and R. T. Scott, “Telomere dna deficiency is associated with development of human embryonic aneuploidy," PLoS Genetics, vol. 7, no. 6, Article ID e1002161, 2011.

[146] R. R. Plentz, B. Schlegelberger, P. Flemming et al., "Telomere shortening correlates with increasing aneuploidy of chromosome 8 in human hepatocellular carcinoma," Hepatology, vol. 42, no. 3, pp. 522-526, 2005. 

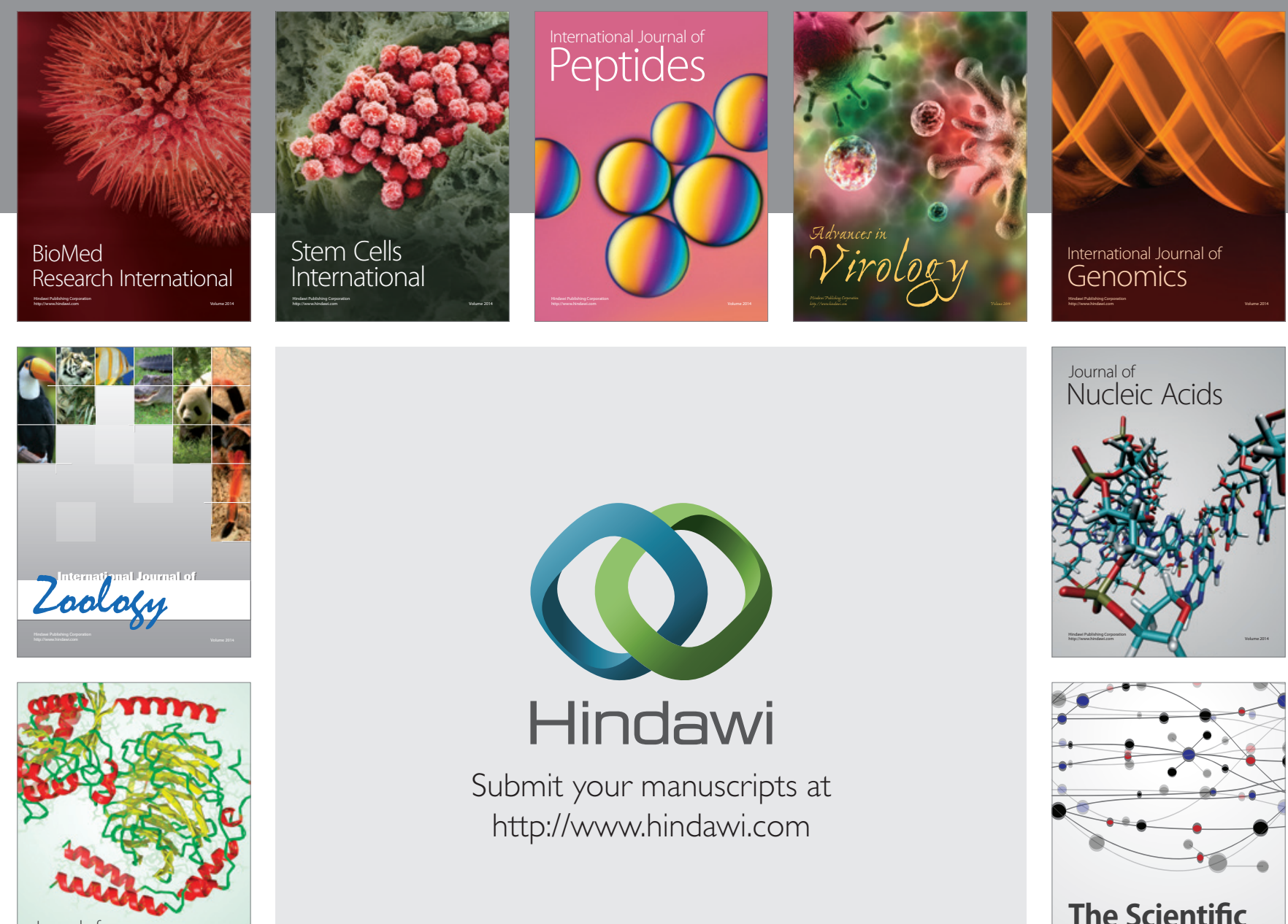

Submit your manuscripts at

http://www.hindawi.com

Journal of
Signal Transduction
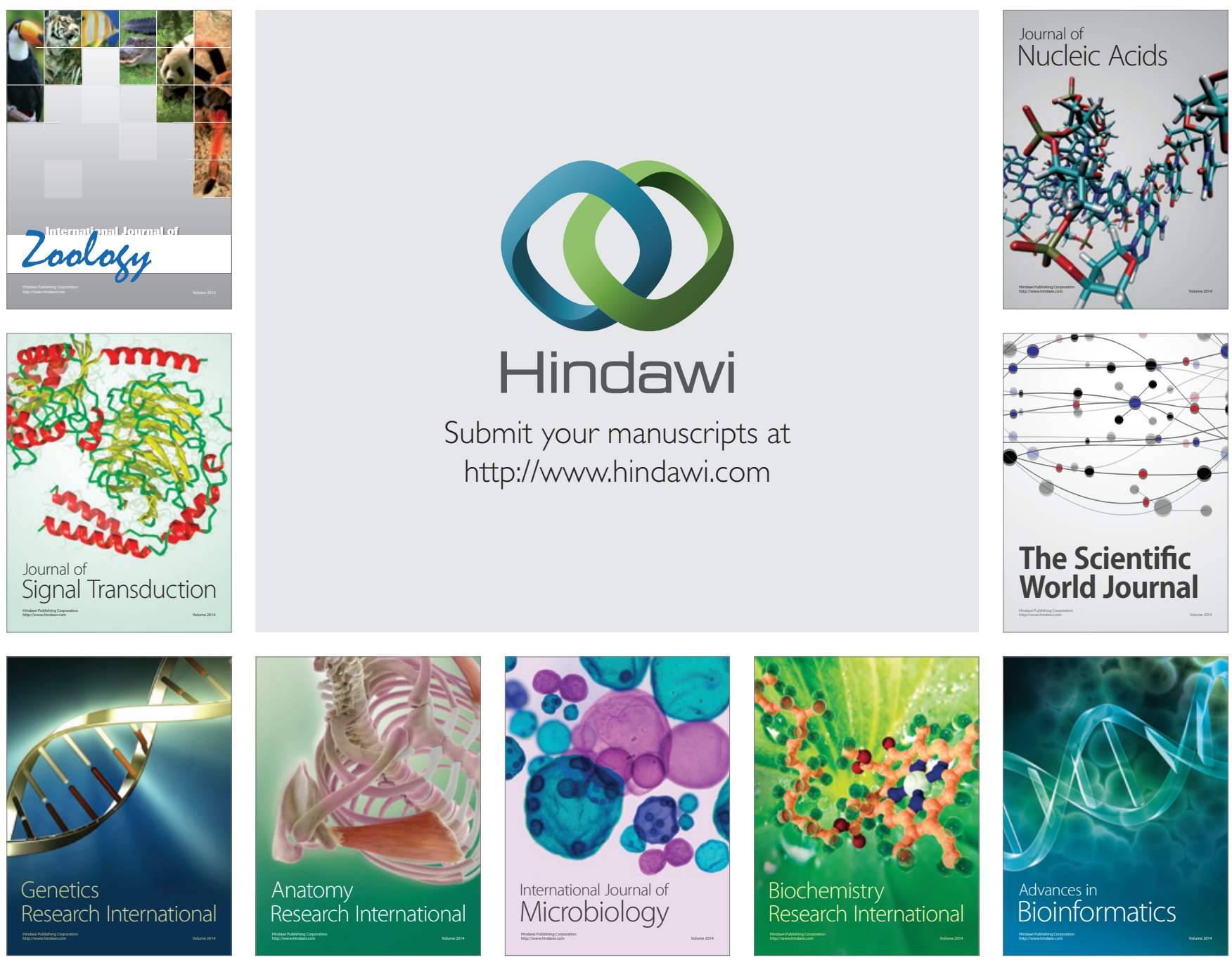

The Scientific World Journal
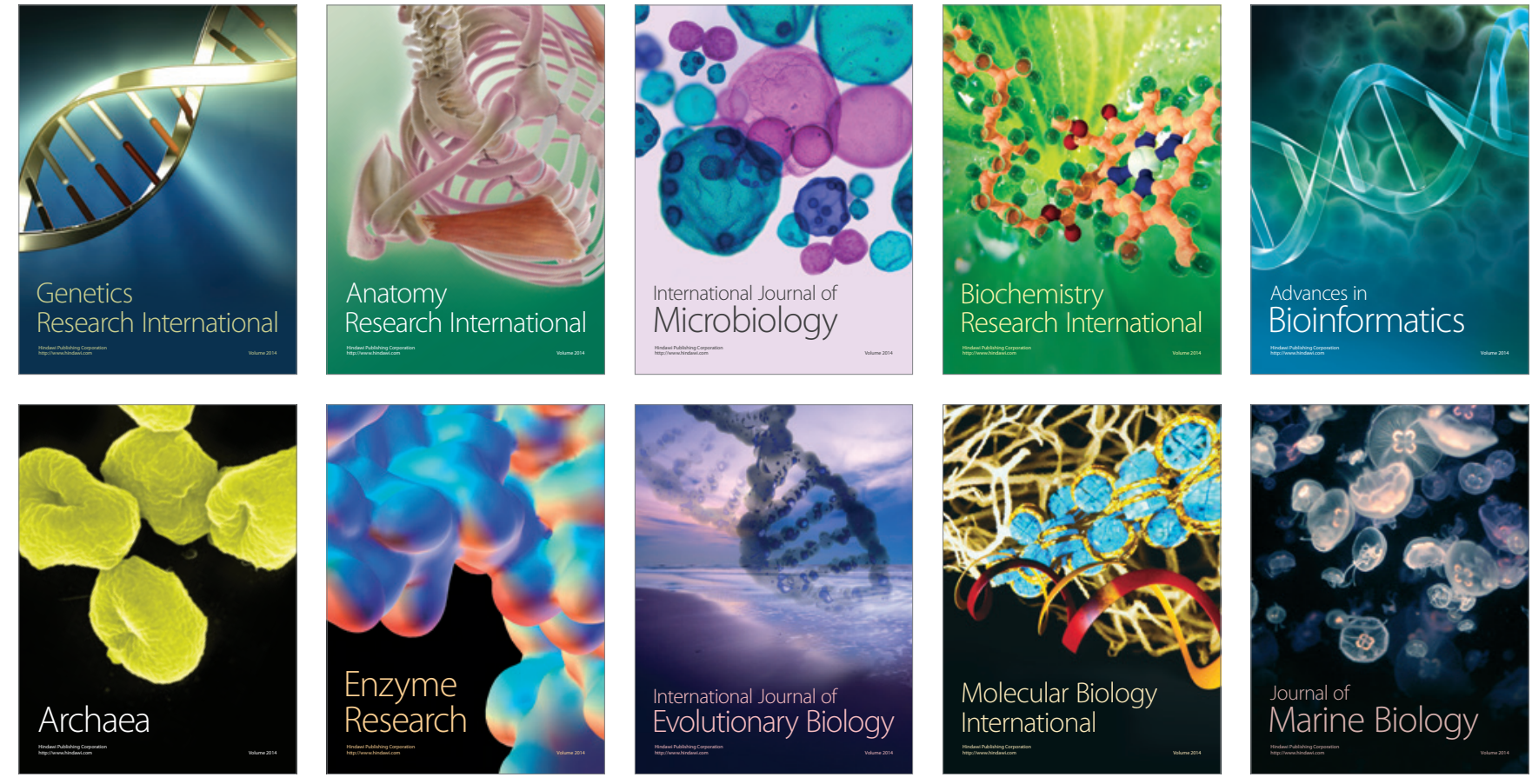